\title{
THE IMPROVEMENT OF THE UNDERSTANDING OF THE STRUGGLE OF THE WARRIORS IN THE DUTCH COLONIAL PERIOD THROUGH TEAMS GAMES TOURNAMENT (TGT) LEARNING MODEL ON STUDENTS OF V GRADE SD $\mathbf{N}$ SURAKARTA ACADEMIC YEAR 2017/2018
}

\author{
Latifah Aulia Harini, Hartono, Hadiyah
}

Universitas Sebelas Maret

latifahaulia04@gmail.com

\begin{tabular}{l} 
Article History \\
\hline accepted 09/07/2018 \\
approved 01/08/2018 \\
published 17/09/2018
\end{tabular}

Keywords

Teams Games

Tournament (TGT),

pemahaman konsep

perjuangan, tokoh

perjuangan, penjajahan

Belanda

\begin{abstract}
The objective of this research is to improve the understanding of the struggle of the warriors in the Dutch colonial period by applying Teams Games Tournament (TGT) learning model on students of $V$ grade SD $N$ Surakarta academic year 2017/2018. This research uses qualitative approach by doing classroom action research with cycle model. The data were collected by doing observation, interview, test, and documentation. The validity of the data is using content validity, triangulation technique including source triangulation and technique triangulation. The data analysis technique in this research uses interactive analysis model that includes data reduction, data display, verification. The conclusion of this research was the implementation of Teams Games Tournament (TGT) learning model, it can improve the understanding of the struggle concept of the warriors during the Dutch colonial period on students of $V$ grade $S D N$ Surakarta academic year 2017/2018.
\end{abstract}

Social, Humanities, and Education Studies (SHEs): Conference Series https://jurnal.uns.ac.id/shes
p-ISSN 2620-9284

e-ISSN 2620-9292 


\section{PENDAHULUAN}

Pendidikan IPS di sekolah dasar merupakan bidang studi yang mempelajari manusia dalam semua aspek kehidupan dan interaksinya dalam masyarakat. Adapun tujuan pendidikan IPS untuk tingkat sekolah dasar, antara lain yaitu: (1) mengajarkan konsep-konsep dasar sosiologi, geografi, ekonomi, sejarah, dan kewarganegaraan, pedagogis dan psikologi, (2) mengembangkan kemampuan berpikir kritis dan kreatif, inkuiri, memecahkan masalah, dan keterampilan sosial, (3) membangun komitmen dan kesadaran terhadap nilai-nilai sosial dan kemanusiaan, (4) meningkatkan kemampuan bekerja sama dan berkompetisi dalam masyarakat yang majemuk, baik secara nasional maupun global. Dengan demikian, peranan IPS sangat penting untuk mendidik siswa mengembangkan pengetahuan, sikap, dan keterampilan peserta didik.

Akan tetapi, pada kenyataannya yang terjadi di kelas V SD N Surakarta pemahaman konsep perjuangan para tokoh pejuang pada masa penjajahan Belanda masih rendah. Permasalahan tersebut terkait dengan salah satu Kompetensi Dasar IPS yang harus dicapai yaitu pada KD 1.1 Mendeskripsikan perjuangan para tokoh pejuang pada masa penjajahan Belanda. Hal tersebut dibuktikan berdasarkan hasil wawancara dengan guru dan siswa, hasil observasi, dan hasil tes pratindakan. Data hasil wawancara dengan guru pada tanggal 15 Desember 2017 diperoleh informasi bahwa: (1) IPS merupakan mata pelajaran yang sulit dipahami siswa, salah satu materi yang dianggap sulit yaitu tentang tokoh perjuangan pada masa penjajahan Belanda, (2) proses pelaksanaan pembelajaran sudah baik. Saat pembelajaran berlangsung, siswa antusias dalam mengikuti pembelajaran. Namun, ketika siswa diberi pertanyaan atau soal, banyak siswa yang kesulitan menjawab, (3) pelaksanaan pembelajaran cenderung berpusat pada guru dan pembelajaran masih text-book oriented dan dilanjutkan dengan mencatat. Selain itu, dari hasil wawancara dengan siswa pada tanggal 15 Desember 2017 diperoleh informasi bahwa: (1) Siswa mengatakan bahwa IPS merupakan mata pelajaran yang sulit karena materinya banyak yang harus dihafalkan, (2) siswa kesulitan dalam memahami materi yang disampaikan oleh guru karena penjelasan materi yang disampaikan kurang menarik, (3) proses pembelajaran cenderung berpusat pada guru, karena lebih banyak menggunakan metode ceramah setelah itu dilanjutkan dengan mencatat atau membuat ringkasan, (4) guru belum pernah mengajar secara berkelompok disertai permainan. Hal tersebut menyebabkan siswa kurang tertarik dan bersemangat dalam mengikuti pembelajaran sehingga siswa kurang memahami materi yang disampaikan guru. Hasil observasi juga menunjukkan hal yang serupa dengan hasil wawancara dengan guru maupun siswa. Berdasarkan hasil wawancara dan observasi, kemudian ditindaklanjuti dengan hasil pre-test yang dilaksanakan pada tanggal 16 Desember 2017. Data yang diperoleh dari hasil pre-test menunjukkan bahwa masih banyak siswa memperoleh nilai di bawah KKM (KKM $\geq 70)$ dengan persentase ketuntasan $16,7 \%$ atau 2 siswa yang dapat mencapai KKM dari total siswa sebanyak 12 siswa dan $83,3 \%$ atau 10 dari 12 siswa tidak mencapai KKM.

Terkait belum optimalnya pemahaman konsep perjuangan para tokoh pejuang pada masa penjajahan Belanda kelas V SD N Surakarta, maka saya menerapkan model pembelajaran Teams Games Tournament (TGT) dalam rangka meningkatkan pemahaman konsep perjuangan para tokoh pejuang pada masa penjajahan Belanda pada siswa kelas V SD N Surakarta.

Menurut Shoimin (2016: 203) model pembelajaran Teams Games Tournament (TGT) adalah salah satu tipe pembelajaran kooperatif yang mudah diterapkan, melibatkan aktivitas seluruh siswa tanpa ada perbedaan status, melibatkan peranan siswa sebagai tutor sebaya yang mengandung unsur permainan dan reinforcement. Pada model ini, siswa dibagi dalam kelompok-kelompok kecil. Setiap kelompok terdiri dari tiga sampai lima siswa yang heterogen. Model pembelajaran TGT menggunakan turnamen akademik, di mana siswa berkompetisi sebagai wakil dari timnya melawan anggota tim yang lain. Komponen-komponen model pembelajaran Teams Games 
Tournament (TGT) memiliki lima komponen utama yaitu (1) penyajian kelas, (2) kelompok, (teams), (3) game, (4) turnamen (turnament), dan (5) penghargaan kelompok (team recognize). Alasan digunakan model TGT karena model ini mendorong siswa yang berkemampuan akademik rendah ikut aktif dan mempunyai peranan penting dalam kelompoknya, menumbuhkan rasa kebersamaan dan saling menghargai sesama anggota kelompoknya, meningkatkan semangat siswa dalam mengikuti pembelajaran karena guru menjanjikan sebuah penghargaan pada kelompok terbaik, dan membuat siswa menjadi senang dalam mengikuti pelajaran karena ada kegiatan permainan berupa turnamen. Dengan demikian, penggunaan model Teams Games Tournament (TGT) dapat membantu siswa dalam meningkatkan pemahaman konsep pada pembelajaran IPS.

\section{METODE}

Penelitian ini dilaksanakan pada siswa kelas V SD N Surakarta tahun ajaran 2017/2018. Waktu penelitian selama bulan Desember 2017 sampai Juli 2018. Subjek dalam penelitian ini adalah guru dan siswa kelas V SD N Surakarta tahun ajaran 2017/2018. Penelitian ini menggunakan pendekatan kualitatif yaitu melalui penelitian tindakan kelas dengan model siklus. Penelitian ini menggunakan prosedur penelitian yang dilakukan melalui 3 siklus. Pada tiap siklusnya memiliki empat tahapan yaitu perencanaan, pelaksanaan, pengamatan, dan refleksi. Data yang dikumpulkan dalam penelitian ini berupa data kuantitatif dan data kualitatif. Data kuantitatif berupa nilai pemahaman konsep perjuangan para tokoh pejuang pada masa penjajahan Belanda. Sedangkan data kualitatif berupa hasil wawancara guru dan siswa, penilaian kinerja guru, penilaian aktivitas siswa dan hasil dokumentasi. Pengumpulan data dilaksanakan dengan teknik observasi, wawancara, tes, dan dokumentasi. Uji validitas data menggunakan validitas isi menggunakan soal tes, pedoman wawancara guru dan siswa, serta pedoman observasi. Selain itu, uji validitas menggunakan teknik triangulasi meliputi triangulasi sumber dan triangulasi teknik. Teknik analisis data dalam penelitian ini menggunakan model analisis interaktif yaitu meliputi reduksi data, penyajian data, dan kesimpulan.

\section{HASIL DAN PEMBAHASAN}

Berdasarkan data yang diperoleh dari hasil wawancara, observasi, dan tes pratindakan menunjukkan bahwa pemahaman konsep perjuangan para tokoh pejuang pada masa penjajahan Belanda pada siswa kelas V SD N Surakarta masih rendah. Hasil nilai tes pratindakan dapat dilihat pada tabel 1.

Tabel 1. Nilai Pemahaman Konsep Perjuangan Para Tokoh Pejuang pada Masa Penjajahan Belanda Pratindakan

\begin{tabular}{lcccc}
\hline Interval & $\begin{array}{c}\text { Median } \\
(\mathrm{xi})\end{array}$ & $\begin{array}{c}\text { Frekuensi } \\
\text { (fi) }\end{array}$ & \multicolumn{2}{c}{ Presentasi } \\
& 38,5 & 1 & 8,3 & Komulatif \\
\hline $35-42$ & 46,5 & 4 & 33,3 & 8,3 \\
$43-50$ & 2 & 16,7 & 58,6 \\
$52-58$ & 54,5 & 3 & 25 & 83,3 \\
$59-66$ & 62,5 & 0 & 0 & 0 \\
$67-74$ & 70,5 & 0 & 16,7 & 100 \\
$75-82$ & 78,5 & 2 & & 100 \\
\hline Jumlah & & 12 & & 55 \\
\hline Rata-rata & & & & $16,7 \%$ \\
\hline Tuntas & & &
\end{tabular}

Berdasarkan Tabel 1 dapat diketahui bahwa nilai rata-rata kelas yaitu 55 . Ketuntasan klasikal sebesar $16,7 \%$ atau 2 siswa memperoleh nilai di atas KKM $(\geq 70)$. 
Sehingga dapat dikatakan bahwa pemahaman konsep siswa pada materi perjuangan para tokoh pejuang pada masa penjajahan Belanda masih rendah. Dengan demikian perlu adanya alternatif pemecahan masalah dengan melaksanakan pembelajaran yang dapat menumbuhkan keaktifan dan partisipasi siswa dalam rangka meningkatkan pemahaman konsep siswa khususnya materi perjuangan para tokoh pejuang pada masa penjajahan Belanda. Pada penelitian ini, guru menerapkan model pembelajaran Teams Games Tournament (TGT).

Setelah diterapkan model pembelajaran TGT pada siklus I menunjukkan adanya peningkatan nilai pemahaman konsep perjuangan para tokoh pejuang pada masa penjajahan Belanda. Hasil peningkatan tersebut dapat dilihat pada Tabel 2 sebagai berikut:

Tabel 2. Nilai Pemahaman Konsep Perjuangan Para Tokoh Pejuang pada Masa Penjajahan Belanda Siklus I

\begin{tabular}{lcccc}
\hline Interval & $\begin{array}{c}\text { Median } \\
(\mathrm{xi})\end{array}$ & $\begin{array}{c}\text { Frekuensi } \\
(\mathrm{fi})\end{array}$ & \multicolumn{2}{c}{ Presentasi } \\
& 43,5 & 5 & 41,7 & 41,7 \\
$40-47$ & 51,5 & 1 & 8,3 & 50 \\
$48-55$ & 1 & 3,3 & 58,3 \\
$56-63$ & 59,5 & 3 & 25 & 83,3 \\
$64-71$ & 67,5 & 2 & 16,7 & 100 \\
$72-79$ & 75,5 & 12 & & 100 \\
\hline Jumlah & & 12 & & 56,87 \\
\hline Rata-rata & & & & $33,3 \%$ \\
\hline Tuntas & & &
\end{tabular}

Data pada tabel di atas menunjukkan bahwa nilai rata-rata kelas yaitu 56,8. Ketuntasan klasikal sebesar $33,3 \%$ atau 4 siswa memperoleh nilai di atas KKM.

Hasil penilaian kinerja guru pada siklus I pertemuan 1 diperoleh skor 2,54 dan pertemuan 2 yaitu 2,77. Sehingga skor rata-rata hasil kinerja guru pada siklus I sebesar 2,66 termasuk dalam kategori baik. Sedangkan hasil penilaian aktivitas siswa pada siklus I pertemuan 1 memperoleh skor 2,00 dan pertemuan 2 yaitu 2,23. Skor rata-rata aktivitas siswa sebesar 2,16 termasuk dalam kategori baik. Hasil pemahaman konsep perjuangan para tokoh pejuang pada masa penjajahan Belanda siklus I belum mencapai target indikator kinerja (80\%) sehingga perlu direfleksikan dan dilakukan perbaikan pada siklus II.

Tabel 3. Nilai Pemahaman Konsep Perjuangan Para Tokoh Pejuang pada Masa Penjajahan Belanda Siklus II

\begin{tabular}{lcccc}
\hline \multirow{2}{*}{ Interval } & $\begin{array}{c}\text { Median } \\
(\mathrm{xi})\end{array}$ & $\begin{array}{c}\text { Frekuensi } \\
(\mathrm{fi})\end{array}$ & \multicolumn{2}{c}{ Presentasi } \\
& Relatif & Komulatif \\
\hline $45-54$ & 49,5 & 3 & 25 & 25 \\
$55-64$ & 59,5 & 1 & 8,3 & 33,3 \\
$65-74$ & 69,5 & 2 & 16,7 & 50 \\
$75-84$ & 79,5 & 5 & 41,7 & 91,7 \\
$85-94$ & 89,5 & 1 & 8,3 & 100 \\
\hline Jumlah & & 12 & & 100 \\
\hline Rata-rata & & & & 67,5 \\
\hline Tuntas & & & & $58,3 \%$ \\
\hline
\end{tabular}

Berdasarkan Tabel 3 menunjukkan bahwa nilai rata-rata kelas yaitu 67,5. Ketuntasan klasikal sebesar $58,3 \%$ atau 7 siswa memperoleh nilai di atas KKM. 
Hasil penilaian kinerja guru pada siklus II pertemuan 1 diperoleh skor 2,68 dan pertemuan 2 yaitu 2,88 . Sehingga skor rata-rata hasil kinerja guru pada siklus II sebesar 2,78 termasuk dalam kategori baik. Sedangkan hasil penilaian aktivitas siswa pada siklus II pertemuan 1 memperoleh skor 2,56 dan pertemuan 2 yaitu 2,69. Skor rata-rata aktivitas siswa sebesar 2,63 termasuk dalam kategori baik. Hasil pehaman konsep perjuangan para tokoh pejuang pada masa penjajahan Belanda siklus II belum mencapai target indikator kinerja $(80 \%)$ sehingga perlu direfleksikan dan dilakukan perbaikan pada siklus III.

Tabel 4. Nilai Pemahaman Konsep Perjuangan Para Tokoh Pejuang pada Masa Penjajahan Belanda Siklus III

\begin{tabular}{|c|c|c|c|c|}
\hline \multirow{2}{*}{ Interval } & \multirow{2}{*}{$\begin{array}{c}\text { Median } \\
\text { (xi) }\end{array}$} & \multirow{2}{*}{$\begin{array}{l}\text { Frekuensi } \\
\text { (fi) }\end{array}$} & \multicolumn{2}{|c|}{ Presentasi } \\
\hline & & & Relatif & Komulatif \\
\hline $66-72$ & 69 & 1 & 8,3 & 8,3 \\
\hline 73-79 & 76 & 2 & 16,7 & 25 \\
\hline $80-86$ & 83 & 4 & 33,3 & 58,3 \\
\hline $87-93$ & 90 & 2 & 16,7 & 75 \\
\hline $94-100$ & 97 & 3 & 25 & 100 \\
\hline Jumlah & & 12 & & 100 \\
\hline Rata-rata & & & & 85,6 \\
\hline Tuntas & & & & $91,7 \%$ \\
\hline
\end{tabular}

Berdasarkan tabel 4 menunjukkan bahwa bahwa nilai rata-rata kelas yaitu 85,6. Ketuntasan klasikal sebesar $91,7 \%$ atau 11 siswa mendapat nilai di atas KKM.

Hasil penilaian kinerja guru pada siklus III pertemuan 1 diperoleh skor 2,96 dan pertemuan 2 yaitu 3,20. Sehingga skor rata-rata hasil kinerja guru pada siklus III sebesar 3,08 termasuk dalam kategori baik. Sedangkan hasil penilaian aktivitas siswa pada siklus III pertemuan 1 memperoleh skor 2,84 dan pertemuan 2 yaitu 3,11. Skor rata-rata aktivitas siswa sebesar 2,98 termasuk dalam kategori baik. Hasil pemahaman konsep perjuangan para tokoh pejuang pada masa penjajahan Belanda siklus III telah mencapai target indikator kinerja $(80 \%)$ sehingga tindakan dihentikan pada siklus ini.

Perbandingan nilai pemahaman konsep antarsiklus dapat dilihat pada gambar 1 .

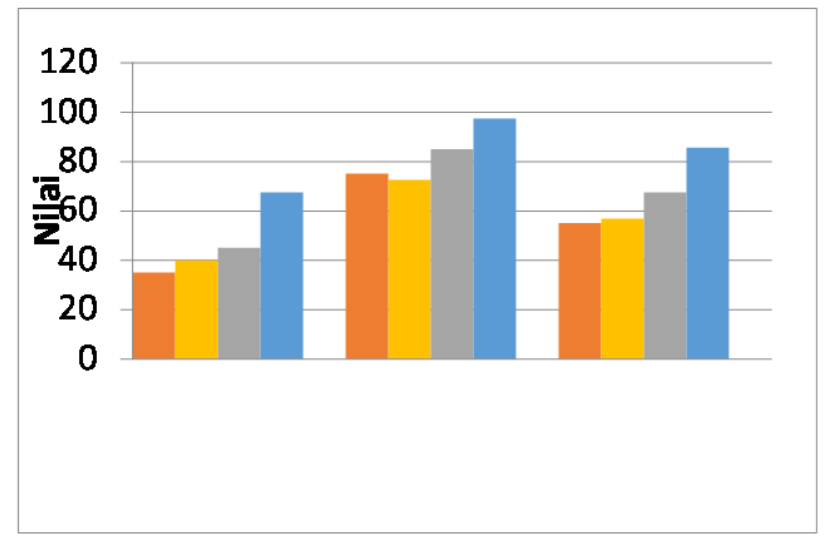

N. Terendah N. Tertinggi N. Rata-rata klasikal

Pratin- Siklus I $\quad$ Siklus II

Gambar 1. Perbandingan Nilai Pemahaman Konsep Antarsiklus 
Berdasarkan hasil penelitian yang diperoleh dapat dinyatakan bahwa penerapan model pembelajaran Teams Games Tournament (TGT) dapat meningkatkan pemahaman konsep perjuangan para tokoh pejuang pada masa penjajahan Belanda pada siswa kelas V SD N Surakarta. Didukung dengan pendapat Huda (2014: 197) yang menjelaskan bahwa model pembelajaran Teams Games Tournament (TGT) merupakan salah satu model pembelajaran kooperatif yang dapat membantu siswa mereview dan menguasai materi pelajaran. Model pembelajaran TGT membantu siswa dalam memahami dan menguasai pembelajaran yang disampaikan guru. Selain itu, didukung juga dengan jurnal "The Effects of Teams Games Tournaments on Achievement, Retention, and Attitudes of Economics Education Students" oleh Micheal M. van Wyk (2011) yang diperoleh hasil bahwa:

The TGT technique is more effective than the lecture method with regard to economics student achievement and student retention of economics content.

Hal tersebut dibuktikan dengan meningkatnya hasil pemahaman konsep perjuangan para tokoh pejuang pada masa penjajahan Belanda dari siklus I, II, dan III. Pada pratindakan ketuntasan siswa sebesar $16,7 \%$, siklus I meningkat menjadi $33,3 \%$, siklus II meningkat lagi menjadi $58,3 \%$, dan pada siklus III ketuntasan mencapai $91,7 \%$. Peningkatan tersebut juga dipengaruhi oleh peningkatan kinerja guru dalam melaksanakan pembelajaran dan peningkatan aktivitas siswa dalam mengikuti pembelajaran. Pada siklus I diperoleh skor rata-rata kinerja guru 2,66, pada siklus II mengalami peningkatan mencapai 2,78 , dan pada siklus III meningkat lagi mencapai 3,08. Meskipun kinerja guru pada penelitian ini sudah dalam kategori baik, namun ada beberapa perbaikan kinerja guru. Perbaikan yang dilakukan di antaranya membuat suasana belajar yang lebih menarik dan menyenangkan, lebih tegas kepada siswa, lebih memantau kegiatan belajar siswa secara menyeluruh serta lebih memantapkan dalam pelaksanaan langkah-langkah pembelajaran.

Melalui penerapan model pembelajaran TGT pada penelitian ini, aktivitas siswa semakin baik. Pada siklus I skor rata-rata aktivitas siswa adalah 2,13, silkus II meningkat menjadi 2,63, dan siklus III lebih meningkat lagi sebesar 2,98. Adanya unsur permainan dan pertandingan pada model pembelajaran TGT, menimbulkan adanya kompetisi sehingga mendorong siswa untuk lebih memahami dan menguasai materi pembelajaran. Seperti pendapat Rusman (2016: 224) yang menyatakan bahwa model pembelajaran TGT melibatkan peran siswa sebagai tutor sebaya, mengandung unsur permainan yang dapat mendorong semangat belajar siswa. Pada penelitian ini, guru berhasil mendorong siswa lebih aktif berdiskusi dalam kegiatan belajar berkelompok. Artinya, melalui model pembelajaran TGT dapat meningkatkan pentingnya rasa kerja sama dalam kelompok. Didukung dengan jurnal "Increasing Civics Learning Achievement by Applying Cooperative Learning: Team Game Tournament Method" oleh Etin Solihatin dan Ali Ozturk (2014) yang diperoleh hasil bahwa:

The students of civics learning class stated that their interest to the civics lesson

had increased, they had motivated and learned the lesson more than before; their

friendship relations had become more important and they understand the importance of studying together in cooperation.

Meningkatnya aspek keaktifan siswa dan kinerja guru dalam pembelajaran memberikan peningkatan pada persentase ketuntasan klasikal nilai pemahaman konsep perjuangan para tokoh pejuang pada masa penjajahan Belanda secara signifikan mencapai $91,7 \%$ pada siklus III. Indikator kinerja penelitian (80\%) sudah tercapai sehingga penelitian dinyatakan berhasil dan siklus dihentikan.

Terjadinya peningkatan pada penelitian ini, sejalan dengan beberapa penelitian yang relevan. Apabila dibandingkan dengan hasil penelitian Huda mengenai pemahaman konsep perjuangan pada masa penjajahan Belanda (2017) dengan ketuntasan klasikal di akhir siklus mencapai $88,64 \%$, penelitian ini menghasilkan nilai yang lebih tinggi. Hal ini karena perbedaan model pembelajaran. Apabila 
dibandingkan dengan penelitian Jalong (2017) dengan ketuntasan di akhir siklus mencapai $100 \%$, penelitian Jalong menghasilkan nilai yang lebih tinggi karena perbedaan materi yang dipelajari.

Berdasarkan penjelasan di atas dapat dikatakan bahwa penerapan model pembelajaran Teams Games Tournament (TGT) yang tepat dapat meningkatkan pemahaman konsep perjuangan para tokoh pejuang pada masa penjajahan Belanda siswa kelas V SD N Surakarta.

\section{SIMPULAN}

Berdasarkan hasil penelitian tindakan kelas yang telah dilaksanakan selama tiga siklus dapat disimpulkan bahwa penerapan model pembelajaran Teams Games Tournament (TGT) dapat meningkatkan pemahaman konsep perjuangan pada masa penjajahan Belanda pada siswa kelas V SD N Surakarta tahun ajaran 2017/2018. Persentase ketuntasan siswa pratindakan sebesar $16,7 \%$ dengan nilai rata-rata kelas 55 , pada siklus I meningkat menjadi $33,3 \%$ dengan nilai rata-rata kelas 56,87 , siklus II meningkat lagi menjadi $58,3 \%$ dengan nilai rata-rata kelas 67,5 , dan pada siklus III ketuntasan mencapai $91,7 \%$ dengan nilai rata-rata kelas 85,6 . Peningkatan tersebut terjadi karena model pembelajaran Teams Games Tournament (TGT) telah berorientasi pada partisipasi aktif siswa terutama pada saat kegiatan games dan turnament. Sehingga siswa terlibat aktif dalam pembelajaran dan memahami materi yang disampaikan. Adanya kendala-kendala dalam pembelajaran melalui penerapan model Teams Games Tournament (TGT) sebisa mungkin harus bisa diminalisir. Oleh karena itu, semua aspek baik dari guru maupun siswa harus diperhatikan untuk mendukung keberhasilan suatu pembelajaran.

\section{DAFTAR PUSTAKA}

Huda, A. N. (2017). Penerapan Model Pembelajaran Concept Attainment Berbantuan Film Dokumenter Penjajahan untuk Meningkatkan Pemahaman Konsep Perjuangan Pada Masa Penjajahan Belanda Pada Siswa Sekolah Dasar. Jurnal Didaktika Dwija Indria, ISSN: 2337-8786, 5-6.

Huda, M. (2014). Model-Model Pengajaran dan Pembelajaran. Yogyakarta: Pustaka Pelajar.

Jalong, L. (2017). Peningkatan Pemahaman Konsep Uang Melalui Model Pembelajaran Kooperatif Tipe Teams Games Tournament pada Siswa Sekolah. Jurnal Didaktika Dwija Indria, ISSN: 2337-8786, 4.

Rusman. (2016). Model-Model Pembelajaran (Pengembangan Profesionalisme Guru). Jakarta: Rajawali Pers.

Shoimin, A. (2016). 68 Model Pembelajaran Inovatif dalam Kurikulum 2013. Yogyakarta: Ar-Ruzz Media.

Solihatin, E. \& Ali O. (2014). Increasing Civics Learning Achievement by Applying Cooperative Learning: Teams Game Tournament Method. Sociology Study, 4 (11), 953.

Wyk, M. M. (2011). The Effects of Teams Games Tournaments on Achievement, Retention, and Attitudes of Economics Education Students. Journal of Social Sciences, 26 (3), 183-193. 